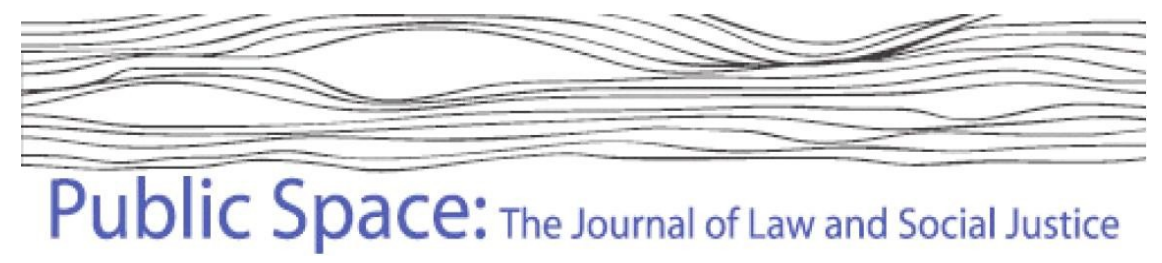

\title{
Mabel Hannah's Justice: a contextual re-reading of \\ Donoghue v Stevenson
}

\section{Honni van Rijswijk ${ }^{1}$}

'I do not think so ill of our jurisprudence as to suppose that its principles are so remote from the ordinary needs of civilized society and the ordinary claims it makes upon its members as to deny a legal remedy where there is so obviously a social wrong'.2

'If law has a soul, then ... it is to be found in the law of tort and, more particularly, in the far-reaching doctrines of negligence'. ${ }^{3}$

'I am very poor, and am not worth in all the world the sum of Five Pounds, my wearing apparel and the subject matter of the said Appeal only excepted...'.4

\footnotetext{
Abstract

${ }^{1}$ Faculty of Law, University of Technology, Sydney.

${ }^{2}$ Donoghue v Stevenson [1932] AC 562, 583 (Lord Atkin).

${ }^{3}$ Desmond Manderson, Proximity, Levinas and The Soul of the Law (McGill-Queen's University Press 2006) 4.

${ }^{4}$ Affadavit sworn by Mrs Donoghue on February 16, 1931 and attached to petition for leave (Journal of the House of Lords 128, 251 cited in Martin Taylor, 'Mrs Donoghue's Journey', in Peter Burns and Susan Lyons (eds), Donoghue v Stevenson and the Modern Law of Negligence: the Paisley Papers: the Proceedings of the Paisley Conference on the Law of Negligence (Continuing Legal Education Society of British Columbia, 1991) 19.
} 
In Donoghue v Stevenson, ${ }^{5}$ the House of Lords established negligence as an independent tort and reformulated the responsibility owed by one person to another in civil society. The accident of Mabel Hannah ${ }^{6}$ finding a snail in her ginger beer became the occasion for the law to disrupt the (then) normal practices of manufacture specifically, and socioeconomic conditions more generally, by introducing attentiveness to vulnerability as a civil ethic. This essay looks back at the case and reads it in its cultural and material contexts-with the intention of illuminating Lord Atkin's neighbour principle within its specific historical framework, and to look again at the justice Mabel Hannah received through the decision. This reading will examine the gap between law and social justice, and re-contextualise the potential of tort law to operate as a kind of civil ethics or system of moral value. In this reading I consider the inflections of the neighbour figure, reading the case's Biblical 'Golden Rule' alongside the anti-ethics of Nietzsche and Freud. I also consider the ongoing paradox of the neighbour as a figure for the recognition of suffering.

\section{Introduction}

In Donoghue $v$ Stevenson, ${ }^{7}$ the House of Lords established negligence as an independent tort and reformulated the responsibility owed by one person to another in civil society. The case is important for historical reasons and there is no doubt that the case matters to contemporary legal interpretation-its 'radiating effects' continue to resonate into the present. ${ }^{8}$ As to why this case also matters to a critical understanding of tort law, I need to start by telling a story. This story is already familiar to most lawyers, but bear with me - it still has its surprising elements, parts that were not told to us in those first torts lectures. This essay is an attempt to look back at the case and

\footnotetext{
${ }^{5}$ [1932] AC 562.

${ }^{6}$ In the legal pleadings, judgments and in subsequent commentary, Mabel Hannah has been referred to as Mrs Mary Donoghue, Mrs May Donoghue and Mrs M'Alister. Following her divorce from her husband in 1928, she reverted to her maiden name of McAllister, but was actually known as 'Mabel Hannah' (Alan Rodger, 'Mrs Donoghue and Alfenus Varus' (1988) 41 Current Legal Problems 1, 3-9, 5). Hannah was her mother's maiden name and Mabel was the name of her daughter, who died as an infant (Rodger, 8). In the House of Lords decision, and in most tort textbooks (where most of us encounter her), she is known as 'Mrs Donoghue'. ${ }^{7}[1932]$ AC 562.

${ }^{8}$ K Warner, 'Judicial Reasoning and Precedent: Negligently Inflicted Psychological Injuries' (1990) 10 Legal Studies (1) 63, 75.
} 
read it in its cultural and material contexts - to understand Lord Atkin's neighbour principle within its specific historical framework, and to look again at the justice Mabel Hannah received through the decision. This reading will examine the gap between law and social justice, and re-contextualise the potential of tort law to operate as a kind of civil ethics or system of moral value. In this reading I consider the inflections of the neighbour figure, reading the case's Biblical 'Golden Rule' alongside the anti-ethics of Nietzsche and Freud. I also consider the ongoing paradox of the neighbour figure.

Negligence imposes on everyone a duty of care owed not to the world generally, but to those who will be foreseeably injured by a failure to take care; liability is determined through the concept of proximity, or neighbourhood, which both produces the duty relationship between the parties, and sets its limits. But the neighbour figure is enigmatic. Who is the speaking - or listening-subject encountering Lord Atkin's question, 'Who, in law, is my neighbour?' And who, in turn, is the neighbour so considered? There is a strange intimacy in this principle, which makes strangers neighbours; there is something beautiful in this ethic, something full of hope. And yet there are crucial limitations concerning who counts as a neighbour, and the ways in which their suffering might count. This contradiction-between the ethic of neighbourhood, and those actually helped by the law - is one that might be answered through an attentiveness to the historical contexts of the case, and through the critical re-telling of its stories. Like all good stories, this one starts with a journey-Mabel Hannah's tram trip from her tenement in the heart of Glasgow to a café in Paisley, Scotland.

It was ten to nine at night on 26 August 1928 when Mabel Hannah, a Glaswegian shop assistant, arrived by tram at the Wellmeadow Café, to meet a friend. Soon after she arrived, this friend ordered and paid for an ice-cream and ginger beer. The ginger beer arrived in an opaque bottle and the proprietor of the Wellmeadow, Mr Francis Minchella, poured some ginger beer over the ice-cream, which Mabel Hannah drank. ${ }^{9}$ Some time later, according to the pleadings:

\footnotetext{
${ }^{9}$ For details of the facts of the case, see Donoghue $v$ Stevenson [1932] AC 562, 562, and the judgment of Lord Buckmaster, 566.
} 
Her friend then lifted the said ginger-beer bottle and was pouring out the remainder of the contents ... when a snail, which had been, unknown to the pursuer, her friend, or the said Mr Minchella, in the bottle, and was in a state of decomposition, floated out of the said bottle. (Art. 2 of Cond.)

Seeing the snail caused Mabel Hannah immediate shock and illness, and over time her condition became worse. On 29 August 1928 she consulted a doctor and was found to be suffering from gastroenteritis caused by the snail-infected ginger-beer. Her condition further worsened and on 16 September 1928 she received emergency treatment at the Glasgow Royal Infirmary, suffering repeated vomiting, acute pain in her stomach, and mental depression. She was rendered unfit for her employment. She lost wages and incurred expense as a result of her injuries and sued the manufacturer of the ginger beer, Mr Stevenson, an Aerated-Water Manufacturer, for $£ 500$ damages for her suffering. ${ }^{10}$

Mabel Hannah's legal position seemed hopeless since, as her friend had bought the drink, the friend and not Mabel Hannah had contracted with the proprietor of the Wellmeadow: therefore, she could not rely on any implied warranty concerning the safety of the drink. ${ }^{11}$ The friend did, however, notice the address of the manufacturer, $\mathrm{Mr}$ Stevenson, on the bottle of ginger beer. The only legal recourse open was to sue $\mathrm{Mr}$ Stevenson in negligence, but at that time, no relationship between manufacturers and end consumers was recognised by the law. There is no information available to indicate how Mabel Hannah found her lawyer, Walter Leechman, but she was fortunate in doing so, as he had recently acted in another Scottish case, Mullen $v A G$ Bar, ${ }^{12}$ which had also reached the Scottish Court of Sessions but had failed for technical reasons. ${ }^{13}$ The case of Mullen $v$ AG Bar concerned, improbably, two plaintiffs finding a mouse in a bottle of ginger beer (if there is a moral rule arising in these cases, it is that one should never drink ginger beer in Scotland). Mabel Hannah's case was

\footnotetext{
${ }^{10}$ See Donoghue v Stevenson [1932] AC 562, 562, and the judgment of Lord Buckmaster, 566.

${ }^{11}$ The gender of the friend is not specified in either the pleadings or the judgment. Taylor speculates that the lawyers and judges refrained from referring to the friend as 'he' throughout because Mabel Hannah was only recently separated from her husband and 'these were not permissive times' (Taylor, above $\mathrm{n} 4$, 19).

${ }^{12}$ (1929) SC 461.

${ }^{13}$ Taylor n 4, 6-8.
}

Public Space: The Journal of Law and Social Justice (2010) Vol 5, Art 1, pp 1-26. 
sufficiently distinct from the facts of Mullen $v A G B a r$ as to avoid its technical difficulties, so Mr Leechman filed a writ in the Scottish Court of Sessions. ${ }^{14}$

How did these inauspicious, somewhat ridiculous facts change modern personal injury law? In the end, the House of Lords found a new relationship of responsibility in lawnot between Mabel Hannah and the proprietor of the café, but between Mabel Hannah and the manufacturer of the ginger beer. The most important judgment in the case was given by Lord Atkin, who held that although he had no contractual connection to her, Mr Stevenson ought to have had someone like Mrs Donoghue 'in contemplation' when producing his ginger beer. ${ }^{15}$ The decision produced a new duty of care between manufacturer and consumer, a relationship which, despite being central to the burgeoning market society of the early twentieth century, had not previously been the subject of tort law. Before this case, manufacturers could send harmful products out into the world with impunity except towards a limited class of people, with whom they had a contract. This point was key to Lord Buckmaster's dissent in Donoghue- - he was critical of the social and economic consequences of the new flexibility of tort, as well as the threat a more powerful tort law posed to the role of contract law in regulating relationships. He focused especially on the significance of the demoted role of contract to the future of trade:

The principle contended for must be this: that the manufacturer, or indeed the repairer, of any article, apart entirely from contract, owes a duty to any person by whom the article is lawfully used to see that it has been carefully constructed. ... The principle of tort lies completely outside the region where such considerations apply, and the duty, if it exists, must extend to every person who, in lawful circumstances, uses the article made. ${ }^{16}$

However, the case is important beyond the introduction of this specific consumer relationship, since Lord Atkin's 'neighbour principle' was a formulation of a general duty of care, which redefined responsibility between individuals in civil society. This relationship of duty changed tort law, from a legal responsibility based on specific

\footnotetext{
${ }^{14}$ Ibid 4.

${ }^{15}$ At 580 .

${ }^{16}$ At 578.
}

Public Space: The Journal of Law and Social Justice (2010) Vol 5, Art 1, pp 1-26. 
categories to one that recognised a general rationale of liability. The case established that tort possessed an underlying logic. Negligence law thereby became adaptive and opened up to new categories of injury and relationship that had previously not been imagined by the courts, thereby 'increasing social obligation'. ${ }^{17}$ In his dissenting judgment, Lord Buckmaster noted, with a tone of crankiness, the expansive consequences of this reasoning: 'If one step,' he said, 'why not fifty?'. ${ }^{18}$

\section{A New Morality: making neighbours out of strangers}

It is significant that the general rationale introduced in Donoghue $v$ Stevenson was based on moral value, and that moral value continues to be of importance to tort law. David Owen calls moral responsibility the 'basic cement' of negligence, ${ }^{19}$ Peter Cane argues negligence law is essentially an ethical system of responsibility; ${ }^{20}$ and Desmond Manderson emphasises the ways in which tort thereby differs from other areas of the law:

It is not the outcome of an agreement founded on self-interest, like a contract. It is not a duty owed to the community as a whole and acted on by the State, like criminal law. It describes a personal responsibility we owe to others which has been placed upon us without our consent. It is a kind of debt that each of us owes to others although we never consciously accrued it. Thus it raises, in a distinctly personal way, one of the oldest questions of law itself: 'Am I my brother's keeper?'21

Tort law has been thought of as a kind of moral praxis - as the real-world, textured compliment to philosophical abstraction. Peter Cane argues that:

...by reason of law's institutional resources, the legal 'version' of responsibility has a richness of detail lacking in the moral 'version' of responsibility. Because law is underwritten by the coercive power of the state, courts cannot leave disputes about responsibility... unresolved...

\footnotetext{
${ }^{17}$ Jane Stapleton, 'The Golden Thread at the Heart of Tort Law: Protection of the Vulnerable' in Peter Cane (ed) Centenary Essays for the High Court of Australia (LexisNexis Sydney, 2004) 61.

${ }^{18}$ At 578 .

${ }^{19}$ David Owen, Philosophical Foundations of Tort Law (Oxford University Press, 1995) 223.

${ }^{20}$ Peter Cane, Centenary Essays for the High Court of Australia (LexisNexis Butterworths, 2004) 24-25.

${ }^{21}$ Manderson n 3, 5.
} 
Morality can afford to be vague and indeterminate to an extent that law cannot. $^{22}$

Further, Cane argues that 'outside of the law, there are relatively few norm-enforcing institutions in civil society'. ${ }^{23}$

Here I would like to revisit Donoghue $v$ Stevenson to demonstrate the ways in which the question of moral value is not straightforward in the case: morality functions in complicated ways, and in relation to a number of other values. These include economic values, as well as the value the individual holds in relation to collective interests. In formulating liability based on the figure of the neighbour, Lord Atkin rejected a prevalent habit of judicial interpretation that was not only based on established categories, but which proceeded incrementally through analogy. The formulation of a general duty was a creative leap in itself, but it also introduced creativity as a practice in judicial recognition of tort claims, and meant judges in future cases need not rely on pre-existing categories in determining claims. Lord Atkin explicitly noted that his general formulation of duty was new for tort law, and implicitly, that it arose through a practice of connection:

It is remarkable how difficult it is to find in the English authorities statements of general application defining the relations between parties that give rise to the duty. The Courts are concerned with the particular relations which come before them in actual litigation, and it is sufficient to say whether the duty exists in those circumstances. The result is that the Courts have been engaged upon an elaborate classification of duties as they exist in respect of property, whether real or personal, with further divisions as to ownership, occupation or control, and distinctions based on the particular relations of the one side or the other, whether manufacturer, salesman or landlord, customer, tenant, stranger, and so on. ${ }^{24}$

\footnotetext{
${ }^{22}$ Cane n 19, 12.

${ }^{23}$ Ibid 25 .

${ }^{24}$ At 580 .
} 
Lord Atkin replaced the old practice of interpretation based on categorization with a method that was not only much more open, but which was (and still is) much more difficult to define. He continued by protesting that law and morality are and should be distinct. But then he went ahead and formulated a general principle that was based on morality anyway:

At present I content myself with pointing out that in English law there must be, and is, some general conception of relations giving rise to a duty of care, of which the particular cases found in the books are but instances. The liability for negligence, whether you style it such or treat it as in other systems as a species of 'culpa,' is no doubt based upon a general public sentiment of moral wrongdoing for which the offender must pay. But acts or omissions which any moral code would censure cannot in a practical world be treated so as to give a right to every person injured by them to demand relief. In this way rules of law arise which limit the range of complainants and the extent of their remedy. The rule that you are to love your neighbour becomes in law, you must not injure your neighbour; and the lawyer's question, Who is my neighbour? receives a restricted reply. You must take reasonable care to avoid acts or omissions which you can reasonably foresee would be likely to injure your neighbour. Who, then, in law is my neighbour? The answer seems to be-persons who are so closely and directly affected by my act that I ought reasonably to have them in contemplation as being so affected when I am directing my mind to the acts or omissions which are called in question. $^{25}$

What kind of morality is this, which makes neighbours out of strangers? Scholars have noted not only the moral foundation of the neighbour principle, but also its ambivalent status as principle. Stapleton argues 'There is no test ... there can be no 'duty test,' given what it is that judges do under the cloak of this analytic label'. ${ }^{26}$ In place of principle, we might think of tort as being organized by a flexible series of practices, which include an ethic of neighbourhood, and to which the aesthetics of the neighbour

\footnotetext{
${ }^{25}$ Ibid.

${ }^{26}$ Stapleton n 16, 60.
}

Public Space: The Journal of Law and Social Justice (2010) Vol 5, Art 1, pp 1-26. 
figure is central. The continuing significance of Lord Atkin's formulation lies not only in its assertion of a moral standard, but also in its function in establishing the importance of certain kinds of relationship in law. The case changed the point of view of manufacturers, and required them to have consumers 'in contemplation.' It also changed the material practices of manufacture, since manufacturers had to be attentive to the risks of their products in new ways. Most profoundly, it challenged the courts' deference to the interests of 'society' and 'economy' (as articulated most forcefully by Lord Buckmaster) and countered these aggregating forces with a sympathy for particular relationships, particular individuals, and for the vulnerability that these particularities exhibited against the forces of society and economy.

Lord Atkin's emphasis on a kind of particularity - a relationship of specific responsibility between neighbours - arises through the language of his judgment, especially in its most famous passage. He inhabits multiple points of view as he describes the duty of care. To begin with, the question of liability is expressed in the first-person singular as 'the lawyer's question, Who is my neighbour?' The next shift in point of view occurs by way of an answer to this question: 'You must take reasonable care to avoid acts or omissions which you can reasonably foresee would be likely to injure your neighbour.' Here, the subject addressed in second-person is ambiguous: at once singular and plural, particular and universal. Lord Atkin returns to the first person point of view: 'Who then, in law, is my neighbour?' and stays in first person to elaborate the obligation of care towards 'persons who are so closely and directly affected by my act that I ought reasonably to have them in contemplation as being so affected when I am directing my mind to the acts or omissions which are called in question.' The imperative operates towards both self and other. It is a 'lawyer's question,' but the question needs to be asked by all members of civil society who might be potentially liable to their neighbours.

The duty of care is a duty between individuals, and is quite different in quality from the social and economic interests defended by Lord Buckmaster - the duty is not owed to the entire world, but to those particular individuals within reasonable contemplation of the doer's acts. Through Lord Atkin's rhetorical moves, the anonymous group referenced by social and economic interests is dissolved, as each member is required to consider the neighboirs who may be harmed by her actions or inactions, and to have

Public Space: The Journal of Law and Social Justice (2010) Vol 5, Art 1, pp 1-26. 
these neighbours in mind as she goes about her life. In doing so, a person cannot rely on established categories of liability to determine her obligation to the other-rather, one must have in mind a flexible approach towards obligation, and be open to multiple and changing responsibilities. The neighbourly mind is a pre-emptive, relational mind. Tort law thereby has the potential to produce a strange new intimacy between people, through this pre-emptive consideration for the other. The obligation is a kind of civil ethics which is also a legal imperative underwritten by economic consequences.

\section{Fetish and Mystification: from dangerous commodities to careless minds}

The formulation of civil ethics in the case occurred specifically through the relationship between manufacturer and consumer. By emphasizing the civil nature of this relationship, Lord Atkin challenged the role of economics in determining relations between people and thereby criticized the organization of relationships in the modern, market society. Lord Atkin did so not only through his articulation of the neighbour principle, but also by reconceptualising the object at the centre of the case, the snail in the bottle. The snail's significance in the previous legal proceedings lay in its status as a dangerous object but Lord Atkin argued that its real significance lay in its status as an effect of a negligent mind. In Lord Atkin's formulation of liability, the snail-object was of peripheral importance and the neighbour-subject moved to the foreground. The birth of negligence law as we know it involved judicial wrestling of the object to reveal the subject behind it, thereby pushing against the reification process of capitalism. For this reason it is worthwhile tracing the story of dangerous objects and their eventual disappearance in Lord Atkin's judgment.

Early tort cases were captivated by dangerous objects. There was a sense in which these things were given a strange kind of agency, in ways that resonate with Bill Brown's theorization of the object in his essay 'Thing Theory'. ${ }^{27}$ Here Brown describes the relationship between danger and the defamiliarisation of objects, arguing:

We begin to confront the thingness of objects when they stop working for us: when the drill breaks, when the car stalls, when the windows get filthy, when their flow within the circuits of production and distribution, consumption and exhibition, has been arrested, however momentarily.

\footnotetext{
${ }^{27}$ Bill Brown, 'Thing Theory' (2001) 28 Critical Inquiry 1, 1-21.
} 
The story of objects asserting themselves as things, then, is the story of a changed relation to the human subject and thus the story of how the thing really names less an object than a particular subject-object relation. ${ }^{28}$

In cases in which dangerous things injured people, commodities took on a life of their own. Through their transformation, and by performing in ways that were not expected, these objects impinged on and shocked with their sudden violence. They were the monsters of commodity capitalism, the horror story of capitalism's dark side.

The law concerning the manufacture of objects up until the case of Donoghue $v$ Stevenson held that liability for defective or dangerous products could only be based in contract. There were only two exceptions where other duties were found: first, in cases of fraud, where any manufacturer with a mind wicked enough to knowingly send a defective object out into the world was held liable for the damage the object inflicted on unsuspecting consumers; and second, in cases in which the object was held to be dangerous in itself. In the second case, manufacturers were only obliged to be careful with respect to objects that were clearly dangerous - not objects that were merely annoying or sickening - and so there developed a substantial body of case law on the question of dangerousness.

There was no evidence that Mr Stevenson knew that his bottle of ginger beer contained a snail, so Mrs Donoghue's case initially relied on the second category of dangerousness. Mrs Donoghue's solicitor was prepared to say that the snail was in fact dangerous and framed the case by arguing it was 'the duty of the defender to exercise the greatest care in order that snails would not get into the said bottle, render[ing] the said ginger beer dangerous and harmful .... ${ }^{29}$ In response, Mr Stevenson's solicitor argued that the law had 'firearms or poisons' in mind, not snails, 'that it could in no way be said that a snail in a bottle was dangerous in itself,' and further, that 'ginger beer is obviously not per se dangerous $3{ }^{30} \mathrm{Mr}$ Stevenson's lawyers argued:

It is impossible, as the Lord Justice Clerk said in Mullen v AG Barr, to assimilate the position of a dealer in gelignite with the position of a

\footnotetext{
${ }^{28}$ Ibid 68 .

${ }^{29}$ At 565 .

${ }^{30}$ At 568 .
}

Public Space: The Journal of Law and Social Justice (2010) Vol 5, Art 1, pp 1-26. 
dealer in ginger beer. And there would be scant logical justification for holding that ginger beer containing a snail, the sight of which may cause a merely temporary sickness in one consumer is, per se dangerous, while a patent lamp with a defect which may cause an explosion injuring half a dozen people is held not to be per se dangerous. ${ }^{31}$

Lord Moncrieff, in the initial Court of Sessions hearing, was prepared to find the snail, and food more generally, a danger in itself:

The danger of infection is such as is or should be known in every domestic kitchen and still room. Tainted food when offered for sale is, in my opinion, amongst the most subtly potent of 'dangerous goods,' and to deal in or prepare such food is highly relevant to infer a duty. ${ }^{32}$

But the Scottish appeal judges disagreed. When the majority of the Scottish appeal judges heard and rejected Mrs Donoghue's claim, they followed their own recent decision in Mullen v AG Barr, ${ }^{33}$ concerning the mouse in the ginger beer. Lord JusticeClerk said:

Now, the only difference-and, so far as I can see, it is not a material difference-between that case and this case is that there we were dealing with a mouse in a ginger-beer bottle, and here we are dealing with a snail in a ginger-beer bottle. Quoad ultra the circumstances appear to be identical. $^{34}$

Accordingly, the Second Division of the Court of Session reviewed the authorities and dismissed Mrs Donoghue's action, affirming their earlier principle in the mouse case. The judges in both Court of Sessions hearings cited a number of cases from the nineteenth century onwards, which had dealt with the issue. They found that a defective railway wagon was held not to be dangerous in itself, ${ }^{35}$ nor was an exploding

\footnotetext{
${ }^{31}$ At 570.

${ }^{32}$ Appeal Papers 6.

33 (1929) SC 461.

${ }^{34}$ Appeal Papers 22.

${ }^{35}$ Caledonian Railway Company v Warwick, $25 \mathrm{R}$ (HL).
} 
paraffin lamp. ${ }^{36}$ Defective hairwash was found to be dangerous, ${ }^{37}$ and gas was found to be inherently dangerous. ${ }^{38}$ In his minority judgment in the House of Lords decision, Lord Buckmaster found, referring to the American case of MacPherson v Buick Motor $\mathrm{Co}{ }^{39}$ that 'a motor car might reasonably be regarded as a dangerous article'. ${ }^{40}$

The story of Donoghue $v$ Stevenson is in part a story about the reversal of this order of the object's power over the subject, as Lord Atkin revealed these objects to be the logical end effects of market processes and systems, where these processes were not abstract and distant, but particular and proximate, produced by people such as the rather commonplace Mr Stevenson. Lord Atkin took hold of any seeming monsters lurking in this story and pushed them firmly back into the mind of their creator, the manufacturer. Lord Atkin crisply dismissed the question of dangerousness altogether:

I do not find it necessary to discuss at length the cases dealing with duties where the thing is dangerous, or, in the narrower category, belongs to a class of things which are dangerous in themselves. I regard the distinction as an unnatural one so far as it is used to serve as a logical differentiation by which to distinguish the existence or non-existence of a legal right. ${ }^{41}$

Lord Atkin saw a problem in a social order where relations between subjects were broken up by the interposition of objects. Lord Atkin's re-reading of the dangerous object thereby connected him to a very unexpected genre of evaluation-that of Marxism, as Lord Atkin's neighbour principle is essentially a refusal of commodity fetishism. According to Karl Marx, 'The fetishism of the commodity,' lies in the fact that 'a definite social relation between men themselves ... assumes here, for them, the fantastic form of a relation between things' ${ }^{42}$ In Capital (1867), Marx deconstructed the 'thingness' of commodities, arguing that commodities obtain their value not from inherent qualities, but rather from their place in interconnected discourses (across

\footnotetext{
${ }^{36}$ Longmeid $v$ Holliday 6 WH \& G Exchequer Reports 761.

${ }^{37}$ George v Skivington LR 5 Ex. 1.

${ }^{38}$ Dominion Natural Gas Co v Collins and Perkins [1909] AC 640, 646.

${ }^{39} 217$ NY 382.

${ }^{40}$ At 577.

${ }^{41}$ At 589.

${ }^{42}$ Karl Marx, Capital: Edited with an Introduction and Notes by David McLellan (Oxford University Press, 2008) 165.
} 
economic, cultural and social domains). Marx arrived at this conclusion through his observation that in the nineteenth century the value of commodities came to exceed their use value; this end value did not arise out of the object itself but rather was an effect of the process of exchange. ${ }^{43}$

Lord Atkin swept away the consideration of objects-dangerous-in-themselves as a ground of liability and replaced this question with a very different consideration: the mind of the manufacturer who produced the object. The terms of inquiry shifted from a debate about which objects might be considered dangerous in themselves - an exploding lamp? a cart that was packed unevenly? - to a debate that emphasized the mind and processes that produced the object. The unlikely result of this tension between object and subject is a new ethics based on an act of imagination that focuses not on the relationship between the object and the person injured but on the creator of the object and the person injured. The quality of mind in this new formulation is not the wicked mind, as in fraud cases, which required actual knowledge of defectiveness, but the negligent mind, the mind that fails to pay attention. In producing his concept of neighbourhood, Lord Atkin began by quoting Lord Esher in Le Lievre v Gould, ${ }^{44}$ who used a spatial metaphor to frame responsibility:

If one man is near to another, or near to the property of another, a duty lies on him not to do that which may cause a personal injury to that other, or may injure his property. ${ }^{45}$

Lord Atkin combined the spatial framework of Lord Esher's dictum with the parable of the Good Samaritan, making neighbourhood a mental rather than, or as well as, a spatial condition. In addition to the economic impact of liability, this new formulation changed the mental and material conditions of manufacture: it meant manufacturers must have consumers 'in contemplation' when going about their business. The manufacturer needed to think of his entire manufacturing process with end-consumers in mind, to consider multiple circumstances in which people might consume his product, and to act with care respect those circumstances to prevent injury.

\footnotetext{
${ }^{43}$ Ibid 163-177.

${ }^{44}$ [1893] 1 QB 491, 497, 504.

${ }^{45}$ At 504, cited by Lord Atkin 582, emphasis in original.
} 
Mabel Hannah, when sitting in her café, had no awareness of how the snail came to be in the bottle. In fact, the inexplicability of the snail probably caused a large part of her shock, which was narrated as a moment of recognition: Mabel Hannah's suffering began not when she initially ingested the snail but when the decomposed snail 'floated' out of the bottle and she realized what her body had already taken in. In the process of investigating the cause of the accident, Mabel Hannah's lawyers deconstructed this shock experience, revealing it to be an effect of a chain of specific events. Shock here was not the effect of a distant series of processes and figures only intimated in the text, but rather caused by a particular party with a negligent mind, who could be held accountable for both actions and omissions. The law asserted authority over the shock experience: it showed that, although dangerous commodities might produce shocks that were experienced as coming out of nowhere, there was, in fact, a certain cause, which the legal process could reveal. Mabel Hannah's lawyers demonstrated that the shock she experienced should not have come as a surprise, given the careless, even disgusting, methods Mr Stevenson employed in his manufacturing processes. Mabel Hannah's lawyers alleged:

[T]hat the defender's system of working his business was defective, in respect that his ginger beer bottles were washed and allowed to stand in places to which it was obvious that snails had freedom of access from outside the defender's premises, and in which, indeed, snails and slimy trails of snails were frequently found. ... The defender well knew, or ought to have known, of the frequent presence of snails in those parts of his premises where the ginger beer bottles were washed and dried, and, further, ought to have known of the danger of small animals (including snails) getting into his ginger beer bottles. (Art. 3 of Cond.)

The writ in the case drew attention not only to the general conditions of the factory, but to the particular, offending snail, with respect to which Mr Stevenson had specific responsibilities:

The pursuer believes and avers that the said snail, in going into the said bottle, left on its path a slimy trail, which should have been obvious to anyone inspecting the said bottle before the ginger beer was put into it. In

Public Space: The Journal of Law and Social Justice (2010) Vol 5, Art 1, pp 1-26. 
any event, the said trail of the snail should easily have been discovered on the bottle before the bottle was sealed, and a proper (or indeed any) inspection would have revealed the presence of the said trail and the said snail, and the said bottle of ginger beer with the snail in it would not have been placed for sale in the said shop. (Art 4. of Cond.)

The pleadings represented capitalism as a constellation of processes, built on the actions of many particular individuals, just as the shock was received by a particular individual. By placing the figures of manufacturer and consumer together side-by-side, as neighbours, the case revealed the disguised violence of capitalism's excesses. In doing so, the case championed the rights of all consumers of 'articles of common household use'; ${ }^{46}$ of such things as ginger beer, washing powder and chocolatesobjects that had none of the sex appeal of things that have had greater claim on the imagination of trauma, such as bombs and even steam trains, but which nevertheless had been the cause of everyday injuries.

\section{Moral Value and Power: the cultural context of Donoghue v Stevenson}

Donoghue $v$ Stevenson contains a number of threads that are true to the spirit of modernism: a clash of interests between the very rich and very poor; a narrative of consumption and new capitalism; and the intersection of abstract, lofty legal principles with the modest, even embarrassing claim of shock arising from indigestion. But the appearance of the neighbour as a way to organise moral value is somewhat surprising in the cultural context of 1932. In contrast to literary modernism's traumatised, anonymous crowds and blasé flâneurs, who wandered the streets in loneliness, chaos and immanent peril, either hopelessly sensitive or hopelessly blunted by random onslaughts, the sudden proximity produced by modern conditions - so sudden and so proximate in the case of accidents causing personal injury-became the occasion in law to create a relationship of connection, based on, of all things, neighbourly duty and responsibility. Modernity is associated with a sentiment of 'ideological shelterlessness,' formed in a 'postsacred, postfeudal world in which all norms and values are open to question'. ${ }^{47}$ Alisdair MacIntyre describes this local context of the

\footnotetext{
${ }^{46}$ At 584.

${ }^{47}$ Singer, Ben, 'Modernity, Hyperstimulus, and the Rise of Popular Sensationalism' in Leo Charney and Vanessa Schwartz (eds), Cinema and the Invention of Modern Life (University of California Press, 1995) 72-99, 72.
}

Public Space: The Journal of Law and Social Justice (2010) Vol 5, Art 1, pp 1-26. 
meaninglessness of ethical value in his book After Virtue. ${ }^{48}$ In 1903, MacIntyre explains, GE Moore published Principia Ethica, which replaced a system of ethics that was duty-based with what has become known as ethical subjectivism or emotivism. ${ }^{49}$ Moore asserted that the value of the 'good' was relative and unprovable: as an 'intuition,' it could be supported by neither evidence nor reasoning; in his view, 'no action is ever right or wrong as such'. ${ }^{50}$ Principia Ethica was immediately and enthusiastically embraced by British modernists, largely because it denied the late nineteenth-century duty-based ethics of their parents. John Maynard Keynes wrote on the occasion of its publication: 'it was exciting, exhilarating, the beginning of a renaissance, the opening of a new heaven on earth'. ${ }^{51}$ Leonard Woolf described it as:

...substituting for the religious and philosophical nightmares, delusions, hallucinations in which Jehovah, Christ and St Paul, Plato, Kant and Hegel had entangled us, the fresh air and pure light of common sense. ${ }^{52}$

On the continent, Freud addressed ethics in Civilization and Its Discontents (1929), and explicitly rejected the imperative of the Golden Rule - he destabilized morality as a natural given, revealing it to be an effect of contests of power. Like Lord Atkin, Freud used the neighbour figure to explain his idea of civil ethics, but with a very different effect. Freud emphasized the hidden aggression behind the relationship of neighbourhood; he criticized the demand to love one's neighbour as a basis for ethical behaviour, arguing that this demand is irrational and against our instincts. Freud argued that physical proximity, far from producing neighbourly sympathy, actually incited aggression:

$[\mathrm{M}]$ en are not gentle creatures who want to be loved, and who at the most can defend themselves if they are attacked; they are, on the contrary, creatures among whose instinctual endowments is to be reckoned a powerful share of aggressiveness. As a result, their neighbour is for them not only a potential helper or sexual object, but also someone who

\footnotetext{
${ }^{48}$ Alisdair MacIntyre, After Virtue (2007).

${ }^{49}$ Ibid 14-16.

${ }^{50}$ Ibid 15 , emphasis in original.

${ }^{51}$ Quoted ibid 14.

${ }^{52}$ Quoted ibid 16.
} 
tempts them to satisfy their aggressiveness on him, to exploit his capacity for work without compensation, to use him sexually without his consent, to seize his possessions, to humiliate him, to cause him pain, to torture and kill him. ${ }^{53}$

For Freud, the instincts that require the regulation of civil society erupt precisely at the intersection of the public and private spheres - that is, between neighbours. Civil society's response to this aggression, which it calls 'ethics,' is in fact a repressive mechanism based on a power relationship:

Civilization, therefore, obtains mastery over the individual's dangerous desire for aggression by weakening and disarming it and by setting up an agency within him to watch over it, like a garrison in a conquered city. ${ }^{54}$

But Lord Atkin's principle is not only an assertion of moral value: it is also an instrumental morality that reorganized power relationships. The power dynamic between manufacturer and consumer was reorganized through the duty of care which, articulated in a moral register, countered the excesses and 'amorality of the market society ${ }^{, 55}$ - its carelessness and its violence-by supporting the claims of consumers. The moral discourse in the case therefore met and superseded another value that had snuck into both culture and law - the unstated but holy value of the bottom line.

The specific protection afforded to the consumer through the case significantly affected the material positions of consumers and producers. But the case had wider effects on the politics of civil society beyond the specific relationship between producer and consumer. The neighbourhood principle also acted partly as a place-holder to counter formulations of liability which privileged social and economic interests over specific relationships and specific harm. The neighbourhood principle insisted on evaluating liability through particular relationships which were not formulaic. It therefore opposed the utilitarian ethic not only of law-as-economics but of other systems that privilege 'the social' domain, or the collective, over the individual: recourse to both economic

\footnotetext{
${ }^{53}$ Sigmund Freud, Civilization and its Discontents (Norton, 2005) 110-111.

${ }^{54}$ Ibid 112.

${ }^{55}$ Walter Benjamin, Illuminations (Harcourt, Brace \& World) 159.
} 
and social values reference value as an aggregation of many interests. Essentially, Lord Atkin's version of morality introduced into tort law a function or technique which protected individual vulnerability from being as easily subordinated to the collective interests of society and economy. For Jane Stapleton, vulnerability is the central value of tort law, the 'golden thread' that forms the 'core moral concern of tort law' ${ }^{56}$ But the value of vulnerability holds political, as well as moral value. The central place of vulnerability to tort has determined its modern role in law and society, and cases continue to stage the competition between the values of vulnerability and individuality against the aggregating forces of society and economy. Donoghue $v$ Stevenson established tort law as a site in which individuals could not only seek individual justice, but also launch systemic critiques against injustices.

\section{Conclusion: measuring the gap between law and justice}

Tort law shows kindness to the neighbour. The accident of Mabel Hannah finding a snail in her ginger beer became the occasion for the law to disrupt the (then) normal practices of manufacture specifically, and socioeconomic conditions more generally, by introducing attentiveness to vulnerability as a civil ethic. The neighbourhood principle also asserted vulnerability as a value relevant to commercial practices, by impacting financially on defendants through the language of the bottom line. The case therefore reconceptualized economic spaces as civic spaces. The kinds of injuries captured by the figure of the neighbour and the relationship of responsibility subsequently made visible new injuries that had previously been invisible to the lawjust as the injury to the end-consumer had been, prior to Donoghue v Stevenson. The relationship of everyday conditions to suffering thereby became a continuing question in tort law, Lord Atkin's judgment providing a mode of recognition for new relationships and injuries. As the processes of market society worked to commercialize all spaces, tort law potentially provided a civilizing buffer.

There are contradictions in the case between the ethic of neighbourhood and the power of law. Lord Atkin's neighbour principle functions partly as an anti-capitalist sentiment. His judgment is a kind of noblesse oblige that is at odds with corporate power-but its ethic of social justice is still supported by power (Lord Atkin's peerage and connections to the landed gentry). It is just a different kind of power to that which

\footnotetext{
${ }^{56}$ Stapleton n 16, 135.
}

Public Space: The Journal of Law and Social Justice (2010) Vol 5, Art 1, pp 1-26. 
arose through the market economy. But the more significant contradiction in the case concerns Mabel Hannah. Mabel Hannah's small legal story connects one aspect of the everyday violence and hardship of her life to wider social and economic worlds. The case made Mabel Hannah's shock a 'social wrong', ${ }^{57}$ thereby fully articulating a civil ethics of trauma, a framework which was present, but not fully emergent, in earlier nervous shock cases. On the face of the text, Donoghue $v$ Stevenson is a story of a consumer who was sickened and shocked when she saw a decomposed snail float out of a bottle. The story seems straightforward, and not particularly tragic: there is even something ridiculous about being injured by a snail. The shock here is more domesticated and controlled than the train or street accidents, which were the focus of nervous shock litigation. The shock is more personalized, local and manageable, but it is nevertheless strange and arresting. It was through degrees of silliness and seriousness, and of high and low registers of experience, that the injury of ingesting a snail changed the civil law so significantly. A kind of familiarity is generated by this narrative, because it does not involve death or terrible injury; and familiarity arises too from the fact that the case deals with common, household, consumable objects. But it is a familiarity that, in the end, is the familiarity of the uncanny: more familiar because it concerns an everyday object, but stranger because this ordinariness has spun out-ofcontrol. The image of the snail in the bottle is funny, weird and embarrassing. The snail appeared unexpectedly in the Wellmeadow Café, and it again appeared unexpectedly in the texts and discussion of the House of Lords, where it was discussed, on 10 December 1931:

...in a committee room of the House of Lords overlooking the gardens beside the Thames where tea is served, [where the] five Law Lords, dressed as was their custom in ordinary suits, sat before a fireplace to hear argument in May Donoghue's case. ${ }^{58}$

There is something uncanny about the snail. But there is also something not quite right about the way in which the law registers Mabel Hannah's suffering through the narrative of the snail-in-the-bottle. For Freud, '... the term 'uncanny' (unheimlich) applies to everything that was intended to remain secret, hidden away, and has come

\footnotetext{
${ }^{57}$ At 583.

58 Taylor n 4, 5 .
}

Public Space: The Journal of Law and Social Justice (2010) Vol 5, Art 1, pp 1-26. 
into the open'. ${ }^{99}$ In German, 'uncanny' is unheimlich, or unhomely, and the uncanny arises out of the ambiguity of home and domestic life. In theorizing the concept, Freud relied on a range of domestic objects and body parts: eyes, eye-sockets, animated dolls, 'severed limbs, a severed head, a hand detached from the arm [and] feet that dance by themselves' ${ }^{60}$ The concept is also heavily gendered - in many of the examples Freud adduces, women are construed as occluded sinkholes of ambiguity, through their connection with quotidian objects such as dolls and eyes.

Mabel Hannah's suffering arises in the law through this strange and disturbing story. At the same time, it is clear that Mabel Hannah touches lawyers in some way-there is a sense that, at its best, the common law should stand up for the shop assistant who suffers following the ingestion of a snail. In 1990, Martin R Taylor, a Canadian lawyer and retired judge, organized a 'Pilgrimage to Paisley' to honor the role of Donoghue $v$ Stevenson in the development of the law of negligence. ${ }^{61}$ In 1988, Allan Rodger, now Lord Rodger of the House of Lords, conducted extensive research on the life of May Donoghue, consulting a range of legal and State records. In an article published in Current Legal Problems, he described the daily hardship of her impoverished life. This research casts Mabel Hannah as a much more tragic figure than is apparent on the face of the legal text.

Mabel Hannah had to be tenacious in pursuing her case, as not only did she have to see her case through the appeals process, but she had to do so with the assistance of counsel who were willing to act without pay. Further, she had to gain the status of pauper in the courts, since she had no means to put up security for costs. Mabel Hannah's petition to appear in forma pauperis was supported by an affidavit in which she swore:

...I am very poor, and am not worth in all the world the sum of Five Pounds, my wearing apparel and the subject matter of the said Appeal

\footnotetext{
${ }^{59}$ Sigmund Freud, in David McLintock and Hugh Haughton (eds) The Uncanny (Penguin Books, 2003) 132.

${ }^{60}$ Ibid 140, 149, 138-40, 150.

${ }^{61}$ Taylor is currently in possession of the 'genuine Stevenson bottle' (Taylor n 4, 19).
}

Public Space: The Journal of Law and Social Justice (2010) Vol 5, Art 1, pp 1-26. 
only excepted, and am, by reason of such my poverty, unable to prosecute the said Appeal. ${ }^{62}$

Attached to her petition was a certificate of poverty signed by a minister and two elders of her church, attesting to Mabel Hannah's poverty. ${ }^{63}$

Prior to her case, Mabel Hannah had experienced a number of traumatic events. She gave birth to three premature children between 1917 and 1920, all of whom died. ${ }^{64}$ The incidence of premature births is consistent with her poverty, and there is evidence that malnutrition was a factor in the death of her daughter Mabel in $1920 .{ }^{65}$ In 1928 she separated from her husband, and she and her surviving son Henry moved in with her husband's family. ${ }^{66}$ In addition to these events, she endured the quotidian shocks and traumas of a working class woman. Following the case, her life continued to be difficult. She carried on working as a shop-assistant, divorced her husband and moved to a Corporation flat. She died of a heart-attack on the 19th March 1958 at Gartloch Mental Hospital, outside Glasgow, at the age of fifty-nine. ${ }^{67}$ Whether Mabel Hannah in fact received material benefit from the case is also a matter of contention. $\mathrm{Mr}$ Stevenson died before she was able to complete her claim but the rumor is that the case settled out of court for the amount of $£ 200$, which would have been a substantial payment for Mabel Hannah, equivalent to two year's wages. ${ }^{68}$ At her death, her total estate was worth $£ 364 .{ }^{69}$

So what story would Mabel Hannah tell of Donoghue v Stevenson, because she is both a central figure to tort, and yet marginal to the forces of law, power and society? The main source of Mabel Hannah's suffering was, no doubt, not finding the snail in the

\footnotetext{
${ }^{62}$ Affadavit sworn on February 16, 1931 and attached to petition for leave (163 Journal of the House of Lords 128, 251 cited in Rodger n 1, 19).

${ }^{63}$ Ibid 4.

${ }^{64}$ Rodger n 1, 5 and 18-19.

${ }^{65}$ Rodger $\mathrm{n} 1,5$.

${ }^{66}$ Ibid.

${ }^{67}$ Rodger $\mathrm{n} 1,9$.

${ }^{68}$ The amount of settlement is noted in Salmond and Heuston on the Law of Tort 346, cited in Rodger $n$ 1, 21. There is no information concerning what kind of shop Mrs Donoghue worked in, but if she had worked in the food or clothes industry, her average annual wage payments in 1932 would have been between $£ 94.6$ and £114.9 (De Grazia and Furlough, The Sex of Things: Gender and Consumption in Historical Perspective (1996) 252, based on calculations in Chapman and Knight, Wages and Salaries in the United Kingdom, 1920-1938 (1953)).

${ }^{69}$ Taylor n 4, 20.
}

Public Space: The Journal of Law and Social Justice (2010) Vol 5, Art 1, pp 1-26. 
bottle of ginger beer, but her difficult daily life, which was nonetheless fairly typical for her gender and social class. However, it was the peculiar and isolated event of finding this snail which made her suffering - framed as 'shock' - visible to the law.

The legal narrative captures one discrete injury of Mabel Hannah's life, but fails to represent her sustained harms, including the damage caused by poverty and her marginal social status. The law represents the injury she received as a consumer, but is this the social injury that the law should have been most eager to recognize and redress? Lord Atkin stated in his judgment:

I do not think so ill of our jurisprudence as to suppose that its principles are so remote from the ordinary needs of civilized society and the ordinary claims it makes upon its members as to deny a legal remedy where there is so obviously a social wrong. ${ }^{70}$

But what counts as a social wrong and how does a particular injury come to matter to the law? Why does the law adjudicate some injuries and not others? What are the circumstances that determine the intervention of the law? These questions describe the limits of tort law's effectiveness, and the limits, too, of its morality. According to Desmond Manderson, it is the neighbour principle itself that exceeds the language and principles of tort law: a 'spirit' of responsibility hovers outside the law, and is constantly referred to by the law, but cannot be reduced to legal rules. ${ }^{71}$ The moral ethic that forms part of tort law establishes a responsibility that has never been realised by the law, and nor has tort 'been entirely comfortable' with this haunting. ${ }^{72}$ But I wonder whether the language of the law is also haunted by a very different, paradoxical haunting, a haunting of the material, which cannot be captured by moral principle.

As described above, the moral principle based on the figure of the neighbour gave rise to a particular responsibility that potentially supports vulnerable subjects against the utilitarian ethic of social and economic values — values that might sacrifice vulnerable individuals to the common good. However, the limitations of the law can be explained

\footnotetext{
${ }^{70}$ At 583 .

${ }^{71}$ Manderson, n 3, 31.

${ }^{72}$ Ibid 5.
} 
by focusing on another kind of particularity. Jacques Derrida argues the relationships between particularity and universality is the essential question of justice in his essay 'The Force of Law' (1992) and describes the ways in which the law evacuates the particular in its application of rules, thereby inherently denying justice. ${ }^{73}$ Here Derrida argues that justice can be distinguished from 'law' (droit) because they have different relationships to particularity and universality. Derrida described the process of adjudication as follows:

Every time...that we placidly apply a good rule to a particular case, to a correctly subsumed example, according to a determinant judgment, we can be sure that law (droit) may find itself accounted for, but certainly not justice. Law (droit) is not justice. Law is the element of calculation, and it is just that there be law, but justice is incalculable. ${ }^{74}$

While law refers to 'the generality of a rule, a norm or a universal imperative', ${ }^{75}$ justice 'always addresses itself to singularity, to the singularity of the other' ${ }^{76}$ Derrida argues that the solution to the problem of the law's relation to justice is to cease to base legal reasoning on the logic of the relation of the particular case to general principle, and to forgo adjudication based on a pattern altogether - for all judgment to be a judgment of single instances:

In short, for a decision to be just and responsible, it must in its proper moment if there is one, be both regulated and without regulation: it must conserve the law and also destroy it or suspend it enough to have to reinvent it in each case, rejustify it, at least reinvent it in the reaffirmation and the new and free confirmation of its principle. Each case is other, each decision is different and requires an absolutely unique interpretation, which no existing, coded rule can or ought to guarantee absolutely. ${ }^{77}$

\footnotetext{
73 Jacques Derrida, 'Force of Law: The "Mystical Foundation of Authority" in Drucilla Cornell, Michell Rosenfield and David Carlson (eds), Deconstruction and the Possibility of Justice (Routledge Books, 1992) 3-67.

${ }^{74}$ Ibid 947.

${ }^{75}$ Ibid 949.

${ }^{76}$ Ibid 955.

${ }^{77}$ Ibid 961.
} 
'Deconstruction is justice,' then, only because it indicates law's status as a practice, a 'force, its movement or its motivation'. ${ }^{78}$

Similarly, in her seminal work on law and literature, Residues of Justice (1996), WaiChee Dimock contrasts law's inadequate treatment of the particular with literature's account. Dimock focuses on the history of the 'unevenness' of justice between, on the one hand, the 'two primary languages of justice, law and philosophy,' which abstract particulars into a narrative of universality; and, on the other, the 'alternative language, the language of literature,' which offers an alternative justice, based on the particular. ${ }^{79}$ For Dimock, legal adjudication is not only a process of abstraction, but "perhaps an exercise in reduction as well, stripping away apparent differences to reveal an underlying order, an order intelligible, in the long run, perhaps only in quantitative terms'. ${ }^{80}$ The law is 'ultimately a form of reification', ${ }^{81}$ a process which makes 'warring particulars' equal. Very little can intervene in this process of reification, and therefore Dimock turns to the domain of literature for a better account of justice. In some ways, Dimock's turning away from the law fails to account for the law's practices. The 'language of formal universals' described by Dimock is only one of the law's languages: ${ }^{82}$ the law is also a site in which a number of different discourses, agents, forces and figures connect and contradict. There is much that is incommensurate and excessive within legal texts, including norms and aesthetics; there is also material specificity within the law's abstractions. Sometimes the law is aware of this gap between principle and text, and of these excesses - and those moments are both interesting and productive - and sometimes it is not. Dimock looks to literature for:

...the abiding presence - the desolation as well as the consolation-of what remains unredressed, unrecovered, noncorresponding. The phenomenon I have in mind is something like that of being 'lost in translation,' a phenomenon at work in any adjudicative process, any

\footnotetext{
${ }^{78}$ Ibid 945, 957.

${ }^{79}$ Wai-chee Dimock, Residues of Justice: Literature, Law, Philosophy (University of California Press, 1996) 8.

${ }^{80}$ Ibid 2.

${ }^{81}$ Ibid 6.

${ }^{82}$ Ibid 2.
} 
attempt to unify two disparate terms, to make them conform to a principle of equivalence. ${ }^{83}$

But that which remains unredressed, remains in the legal text, and can be analyzed. Dimock turns to literature also for:

...a critical practice responsive to what we might call the cognitive residues of a text, responsive to what remains not exhausted, not encompassed by its supposed resolution. ${ }^{84}$

Yet legal texts are also haunted. The law uses logic, fictions and devices to form decisions based on commensurability; but the excesses remain in the text. In legal cases there is a surprising amount of material that is imaginative, irrational, subjective, and contradictory to the final decision, to dominant legal theory and to dominant culture. In case law there is always play between the very particular factual circumstances with which the court is presented and general principles, a dialectic that moves back and forth, and which is never adequately resolved. Mabel Hannah continues to be a presence in tort law, as one of its haunting figures. Officially, she is a figure of consumer disappointment and mild trauma; unofficially, her suffering marks the ways in which the law, in its adjudication of injuries, is partial and selective. The question is whether this haunting and excessive can be incorporated by the lawwhether the law is capable of a self-reflexive move that would include awareness of the injuries it is able to adjudicate. Is the law capable of recognising whose suffering matters to it, and why?

\footnotetext{
${ }^{83}$ Ibid 6.

${ }^{84}$ Ibid 141.
}

Public Space: The Journal of Law and Social Justice (2010) Vol 5, Art 1, pp 1-26. 